$\begin{array}{ll} & \text { Etnográfica } \\ \text { etnográfica } & \text { Revista do Centro em Rede de Investigação em }\end{array}$

Antropologia

vol. $13(2) \mid 2009$

Vol. $13(2)$

\title{
Mais de mil e uma noites de experiência etnográfica: uma construção metodológica para pesquisadores-performers da religião
}

More than a thousand nights of ethnographic experience: a methodological construction for researcher-performers of religion

\section{Francirosy Campos Barbosa Ferreira}

\section{(2) OpenEdition}

\section{Journals}

Edição electrónica

URL: https://journals.openedition.org/etnografica/1166

DOI: 10.4000/etnografica. 1166

ISSN: 2182-2891

\section{Editora}

Centro em Rede de Investigação em Antropologia

\section{Edição impressa}

Data de publição: 1 novembro 2009

Paginação: 441-464

ISSN: 0873-6561

\section{Refêrencia eletrónica}

Francirosy Campos Barbosa Ferreira, «Mais de mil e uma noites de experiência etnográfica: uma construção metodológica para pesquisadores-performers da religião», Etnográfica [Online], vol. 13 (2) | 2009, posto online no dia 16 maio 2012, consultado o 12 fevereiro 2022. URL: http:// journals.openedition.org/etnografica/1166 ; DOI: https://doi.org/10.4000/etnografica.1166

\section{(c) (†) \&}

Etnográfica is licensed under a Creative Commons Attribution-NonCommercial 4.0 International License. 


\section{Mais de mil e uma noites de experiência etnográfica: uma construção metodológica para pesquisadores-performers da religião ${ }^{1}$}

\section{Francirosy Campos Barbosa Ferreira}

Este texto busca apresentar uma experiência etnográfica realizada em duas comunidades islâmicas em São Paulo e São Bernardo do Campo, Brasil, no âmbito do meu doutorado. Esta pesquisa estabelece um diálogo profícuo com a antropologia da performance e da experiência (ritual) proposta por Victor Turner, Richard Schechner e Ronald Grimes, sendo permeada também pela teoria do "ser afetado" de Favret-Saada. Busco desenvolver, portanto, uma metodologia que abarque tanto a antropologia da performance quanto a antropologia da religião. Para isso, procurei (a) argumentar a respeito da pesquisadora-performer, sendo esta mulher, mãe e antropóloga, e sobre o modo como esses elementos contribuem para uma etnografia performativa; (b) apresentar o percurso etnográfico; (c) destacar a experiência em um acampamento islâmico.

PALAVRAS-CHAVE: antropologia da performance, antropologia da religião, Islã, gênero, etnografia, metodologia.

"Quando nasci, um anjo torto desses que vivem na sombra disse: Vai, Carlos! ser gauche na vida." Drummond de Andrade (1999: 11)

\section{O TRECHO DO POEMA DE CARLOS DRUMMOND DE ANDRADE QUE escolhi como epígrafe deste artigo permite uma poética analogia com a expres- são que assumi em minha vida desde os 14 anos, quando o li pela primeira vez. Confesso que várias vezes ouvi uma voz suave que me dizia: Vai, Franci,}

l Sherazade levou mil e uma noites para convencer o rei a não matá-la, eu levei mais de mil e uma noites para produzir minha etnografia, de que resultou a minha tese de doutorado, intitulada Entre Arabescos, Luas e Tâmaras: Performances Islâmicas em São Paulo (Ferreira 2007), e ainda os vídeos que dirigi, Allahu Akbar (Ferreira 2006), Sacrifício (Ferreira 2007a) e Vozes do Islã (Ferreira 2007b). Este trabalho contou com o apoio do CNPq durante dois anos. Agradeço e dedico este artigo a Sylvia Caiuby Novaes, pela sua infinita generosidade. Tê-la como orientadora foi uma dádiva. 
ser gauche na vida! Na verdade, gauche, para mim, não se resumia apenas a ser de esquerda, mas era estar à margem, fora dos círculos, fora dos tempos, na fronteira dos riscos daí decorrentes. A escolha da antropologia já foi, sobretudo, uma atitude gauche. Além de ser mulher e mãe, resolvi ser antropóloga e, por fim, pesquisadora de comunidades islâmicas, em São Paulo, desde 1998. Este texto busca, portanto, apresentar a experiência etnográfica durante minha pesquisa de campo, os diálogos estabelecidos e os elementos que delineiam a minha própria performance em campo.

Em sintonia com a idéia de Turner $(1982,1986)$ de que a antropologia é a ciência que está mais profundamente enraizada na experiência social e subjetiva do investigador, trago como questão de fundo pensar sobre o lugar que ocupam pesquisador e pesquisado no processo de produção etnográfica, com a finalidade de problematizar a própria metodologia empregada - a observação participante e o lugar da pesquisadora-performer no diálogo construído. Em certa medida, ser gauche é, sobretudo, correr riscos. Nas palavras de Schechner (1985), o pesquisador está lá para ver e ele é visto. Sua presença "é um convite à atuação". O que o diferencia dos demais performers é sua ambigüidade. Ele é um "não performer" e um "não-não-performer"; não é um espectador nem um não-espectador. Ele está entre (in between) dois papéis, assim como entre duas culturas. No campo, ele representa - querendo ou não - sua cultura de origem; de volta para casa, representa a cultura que estudou (Hikiji 2006: 223). Ronald Grimes, em Beginnings in Ritual Studies, ilumina nossa metodologia quando apresenta o que lhe foi proposto por um colega: "Put yourself in that posture; maybe you will learn more about its meaning" (1995: 5). Isto não implica tornar-se ator ou religioso, mas sim aprender a postura corporal observada em campo (1995: 20).

Deste modo, para compreender os seus sujeitos e transmitir o que conseguiu compreender, o pesquisador encontra-se sempre no meio do caminho. Mais do que isso, ele procura estabelecer um diálogo em campo que faça sentido para ambos: pesquisador e pesquisados. Trata-se de um lugar de "representação" que é salutar, na medida que as diferenças diminuem ou se alargam, dentro e fora do campo etnográfico.

Em outras palavras, como aponta Clifford: "Se a etnografia produz interpretações culturais através de intensas experiências de pesquisa, como uma experiência incontrolável se transforma num relato escrito e legítimo?" (1998: 21) Este é o movimento deste artigo, construir um relato que abarque a experiência da pesquisa e que, ao mesmo tempo, exponha o outro e o seu intérprete, a fim de contribuir para uma metodologia para pesquisadores-performers em contexto islâmico.

Talvez seja um risco iniciar um trabalho apresentando os "bastidores" de uma pesquisa, já que, na maioria das vezes, esses comentários costumam estar destinados às notas de rodapé. Porém, uma vez que a presença do pesquisador em campo altera o próprio campo (Clifford 1998), faz-se necessário esclarecer os posicionamentos e escolhas que foram realizados no recorte, delimitação e inscrição da pesquisa. 
Começar pela apresentação da minha "voz" dentre várias é também um perigo, mas "Field experience is indeed a "personal voyage of self-discovery"” (Bruner 1986: 15). Risco assumido, incorro na idéia de que as etnografias são frutos de reflexões construídas, "agenciadas", não de forma solitária, mas nos constantes embates que se dão, tanto no campo junto aos interlocutores, sujeitos da pesquisa, quanto na academia entre meus pares. Vale lembrar que nem uns nem outros são unidades monolíticas, e que conflitos a respeito de questões teóricas e dos entendimentos do campo estarão sempre presentes nestes dois âmbitos de construção do conhecimento.

A verdade é que fui afetada, como bem afirma Favret-Saada (2005: 155) ao sugerir que os antropólogos não devem ignorar ou negar seu lugar na experiência humana. Seguindo esta autora, para quem é preciso resgatar a "sensibilidade" presente na relação sujeito-"objeto", procurei, neste artigo, não me desvincular dos afetos e do que realmente me afetava. A sensibilidade estará presente, não havendo como desvincular a pesquisadora-cientista da mulher que ouve o sermão, a reza, ou participa das festas.

Cabe dizer que desde sempre o antropólogo vem pensando o seu papel como aquele que "(d)escreve" a cultura. Na verdade, como bem nos lembra Teresa Caldeira, nós evocamos, sugerimos, provocamos, ironizamos, mas não descrevemos culturas (1988: 142). Não nos interessa mais recriar a "totalidade”, se é que isto algum dia foi possível, mas interessa-nos a negociação, o diálogo, a observação participante, assim como me interessa também ser afetada para provocar a mesma sensibilidade em quem me lê.

Exponho agora alguns dos aspectos que considerei importantes para explicitar o ser afetado. Para isso, evoco um ponto peculiar da minha biografia que, acredito, afetou a tessitura deste texto e a metodologia empregue: refiro-me (a) ao fato de ser mulher, (b) ao percurso da pesquisa, (c) à experiência no acampamento islâmico.

\section{SER MULHER: UMA QUESTÃO DE GÊNERO?²}

Seguindo algumas autoras, partirei do pressuposto de que ser mulher ${ }^{3}$ faz diferença, em contexto islâmico, ou, melhor dizendo, em qualquer contexto

2 Vale considerar gênero nos moldes propostos por Heloisa Buarque de Almeida: "Não pretendo que a categoria gênero seja apenas pensada como diferença sexual, ou a oposição entre homens e mulheres, mesmo se construída cultural e socialmente - mas é uma oposição entre comportamentos masculinos e femininos que tenho que chamar a atenção para analisar algumas dificuldades durante o trabalho de campo. Porque a divisão sexual é essencialmente um processo cultural, não há uma "essência" que defina o gênero independentemente do contexto histórico e cultural - tudo é relativamente construído, sendo as atribuições de gênero reelaboradas nas situações específicas. São estas reelaborações que permitem à antropóloga ir além das restrições normalmente impostas às mulheres na sociedade estudada" (2001: 53).

3 Como afirma Judith Butler, é importante estar "Ciente é claro que isso não é tudo o que esse alguém é" (Butler 2003a: 20). Sabe-se, portanto, que "se tornou impossível separar a noção de gênero das interseções políticas e culturais em que variavelmente ela é produzida e mantida” [continua] 
de pesquisa, e não estou sozinha nesta proposição. Maria Cardeira da Silva afirma: "Claro que o facto de ser mulher, em trabalho de campo, teve um papel decisivo na desconstrução das clássicas dicotomias que opõem feminino/masculino, natureza/cultura, espaço público/espaço doméstico..." (2004: 2). Ainda na esteira deste raciocínio, Mariza Corrêa complementa: "As pessoas não podem mais ir inocentes para o campo, achando que não faz diferença quem eu sou, de onde eu venho, o que eu digo e o que eu penso" (em Abreu et al. 2003: 1 10). Aprendi isso na "materialidade" do meu corpo, para usar uma expressão de Butler (2003a), pois pressupõe-se que as normas regulatórias do "sexo" trabalhem de um modo performativo, ao construírem a materialidade dos corpos e, mais especificamente, ao materializarem o sexo do corpo, etc. (Butler 2003b: 154). A performance, para esta autora, é a própria condição de subversão, na medida em que, ao mimetizarmos as injunções normativas, nos é possível deslocar, recontextualizar e prefigurar novos contornos de gênero.

No campo, ser mulher ganha destaque porque tenho um lugar específico entre aquelas pessoas - o lugar que o grupo reserva ao sexo feminino ${ }^{4}-$, embora tenha me esforçado para me aproximar tanto de homens quanto de mulheres e tanto uns como outros sejam meus interlocutores. Assim, sempre busquei conversar da mesma forma com homens ou mulheres, fazendo as perguntas que considerei pertinentes e, talvez por isso, ganhando o apelido de subversiva dentro do grupo.

É evidente que minha performance é situacional, e isso não apenas me ajuda a perguntar as mesmas coisas, com ênfases e modos diferentes, mas também a circular com a "mesma" desenvoltura pelos espaços masculinos e femininos. Andar por entre as veredas islâmicas é como aprender a circular em universos únicos, onde a espacialidade também é constituída de muitos ruídos e textos que contribuem para a constituição da performance assumida. É um universo de meandros, de gentilezas, de comportamento recatado, olhar baixo, ouvidos atentos, gestos comedidos, e até mesmo extravagantes, dependendo da situação. Assim, a performance não está só na materialidade do corpo, mas no entorno, nas cercanias e nos circuitos da ação.

[continuação] (Butler 2003a: 20). Vale a pena ressaltar que não pretendo produzir com essa expressão um sujeito trans-histórico ou transcultural. Minha preocupação é exatamente como essa distinção (homem-mulher) é produzida nesse contexto especifico. Nesse sentido, sigo o grande salto dado por Butler quando ela diz que talvez o sexo sempre tenha sido o gênero, de forma que a distinção sexo/gênero não faz sentido.

4 Fatima Mernissi, socióloga marroquina, relata que seu pai sempre dizia que os problemas com os cristãos começavam, da mesma forma que com as mulheres, quando não se respeita a hudud, ou fronteira sagrada. Ela conta que nasceu dentro de um caos, porque nem os cristãos nem as mulheres aceitavam as fronteiras (Mernissi 1999 [1994]: 9-11). 


\section{O PERCURSO DA PESQUISA: APRENDENDO A SER/NÃO SER MUÇULMANA}

Em 1998 vislumbrei a possibilidade, já como membro do Gravi (Grupo de Antropologia Visual da USP), de estudar o uso da imagem fotográfica pelos muçulmanos que residiam no bairro do Brás em São Paulo, tendo em vista que no Islã o culto da imagem é restrito (Ferreira 2002, 2004, 2006, 2009).

$\mathrm{Na}$ dissertação de mestrado relatei como tive acesso ao grupo (Ferreira 2001), mas vale a pena destacar que a entrada foi facilitada quando souberam que eu tinha filhos. Sem falar que três é um número bem razoável, em se tratando de comunidade islâmica, onde a média de filhos é de três ou quatro, sendo raro ter menos. Sentindo-me em casa, ao menos neste quesito, iniciei a tentativa de apreensão do universo islâmico à minha volta. Assim, falar dos filhos, da maternidade, foi uma boa estratégia frentes às mulheres muçulmanas. Tê-los foi uma dádiva para a pesquisa e para a vida. Naquela época, os meus eram bem menores (estando com seis, quatro e dois anos). Dez anos depois, a inserção deles também mudou. Os mais velhos me acompanham ao campo e gostam. Gabriel, meu primogênito, tem sido um aprendiz de antropólogo e vez ou outra fotografa, dá palpites, me avisa quando o sheik aparece na TV, ajuda nas filmagens. Quer me acompanhar em dias de festa. Os mais novos já começaram a comparar as religiões de que ouvem falar na escola e aquela que a mãe estuda. Mundo fascinante esse, o das descobertas. A construção de um trabalho de pesquisa mobiliza não só a academia, mas a família e os amigos. Surge assim o terceiro dado importante da "construção" da pesquisadora-performer, agora uma sobreposição de identidades dentre as quais se destaca a de mulher, a de antropóloga e a de mãe.

Durante o mestrado, o campo se concentrava em duas comunidades: a Mesquita Brasil e o Centro Islâmico do Brás. A necessidade de ter um espaço para oração e para reuniões diversas fez com que imigrantes palestinos fundassem no Brasil, em 1927, a Sociedade Beneficente Muçulmana Palestina de São Paulo, que, em 1929, teve suprimida a palavra "palestina" de seu nome, para favorecer a adesão de outros povos ao grupo. Um de seus objetivos era construir uma escola para alfabetizar os novos imigrantes na língua portuguesa, mas tamanho foi o empenho da comunidade que passou a perseguir também a construção de uma mesquita, originando a primeira mesquita fundada em nosso país, em 1946: a Mesquita Brasil (ou Mesquita São Paulo, como é também conhecida). Localizada no bairro do Cambuci, próximo à avenida do Estado (centro/sul), foi erguida com o apoio de imigrantes árabes, que chegaram ao Brasil entre as duas grandes guerras mundiais.

A comunidade do Brás, composta por aproximadamente duzentas famílias e seus descendentes e por libaneses da cidade de Trípoli, passou, nos últimos quinze anos, por transformações em seus hábitos e costumes religiosos. A maioria das mulheres já chegou ao Brasil sem o véu e poucas continuaram 
a usá-lo, por medo de serem hostilizadas. Em geral, as mulheres mais velhas permaneceram usando o véu, e as moças recém-casadas deixaram de usá-lo. A religião passou a ser algo distante, apenas uma referência e não uma prática cotidiana. A preocupação desses primeiros imigrantes era basicamente ganhar dinheiro e voltar para sua terra de origem.

Um exemplo interessante a respeito de mulheres muçulmanas em situação de diáspora é o trabalho de Godinho (2007: 105-107). A autora verificou que as circunstâncias da imigração favoreceram a prática religiosa das muçulmanas, pois essas relataram que nunca entraram num local de culto na Guiné-Bissau, onde o lugar de oração era restrito aos homens e às mulheres mais velhas. A religião, segundo Godinho, apresenta múltiplos significados, entre eles o caráter protetor ou sua relevância na educação dos filhos. Esses aspectos também serão observados no Brasil. ${ }^{5}$

No doutorado passei a visitar outras duas mesquitas: a Mesquita de Santo Amaro e a de São Bernardo do Campo. A Mesquita de Santo Amaro foi fundada em 1977, na zona sul de São Paulo, com aproximadamente 500 famílias muçulmanas residentes nessa região. ${ }^{6} \mathrm{O}$ terreno em que se instalou a Sociedade era uma chácara que foi comprada com a ajuda de muçulmanos, contando atualmente com o apoio do Ministério de Awcaf do Egito, que envia um sheik a cada dois ou três anos. A Mesquita de São Bernardo do Campo é a única mesquita da região do ABCD. ${ }^{7}$ Foi inaugurada em 1990, mais ou menos seis anos depois do início de sua construção. No período que antecedeu a construção, as

5 Para aprofundamento do tema das mulheres muçulmanas em diáspora, sugiro algumas leituras: Andezian (1986), Salih (2003), Al-Ali, Black e Koser (2001), Abranches (2007).

6 A quantificação dos muçulmanos é algo ainda a ser feito. A comunidade revela que existem 1,5 milhão de muçulmanos no Brasil. Estes dados não são comprovados pelos geógrafos Waniez e Brustlein (2001), que afirmam que o número gira em torno dos 200 mil muçulmanos. O Censo de 1991 indica uma proporção muito pequena de muçulmanos, em torno de 8 mil. Waniez e Brustlein afirmam que a população muçulmana residente no Brasil em 1991 era majoritariamente urbana $(99,4 \%$ contra os $76,4 \%$ do total de brasileiros), masculina (59,5\% contra o total de 49,4\%) e de cor branca $(87,9 \%$ contra a totalidade de $51,6 \%$ ). Indicam que mais de um quarto dos muçulmanos no Brasil não possuem a nacionalidade brasileira $(28,2 \%$, contra os $0,5 \%$ do total da população urbana). A nacionalidade brasileira foi fruto da naturalização de 12,6\% deles, contra $0,1 \%$ da população urbana nacional. Destacam que os muçulmanos oriundos da África correspondem a 2,5\% dos naturalizados e 5,8\% dos estrangeiros. Temos ainda que $92,8 \%$ dos muçulmanos são alfabetizados, contra $82,2 \%$ da população urbana e 75,8\% do total de brasileiros. Assim, 13,5\% têm nível superior contra apenas 4,8\% da população urbana e 3,7\% dos brasileiros em geral. O setor comercial concentra quase $60 \%$ dos muçulmanos que desempenham este tipo de atividade, contra 15,2\% da população urbana. O setor de prestação de serviços ocupa cerca de $10 \%$ dos muçulmanos, contra os $21,1 \%$ dos brasileiros residentes nas cidades. Em torno de 40\% dos muçulmanos são empregadores, contra apenas 4,3\% da população urbana. Em relação aos brasileiros, os muçulmanos apresentam um rendimento mais elevado quanto aos salários mínimos mensais recebidos por pessoas de uma mesma família. Em torno de 13,7\% dos muçulmanos recebem um salário mínimo ou menos, contra 55,7\% da população urbana.

7 A região do $\mathrm{ABCD}$, assim chamada por causa das iniciais dos topónimos, é correspondente às cidades de Santo André, São Bernardo do Campo, São Caetano e Diadema. 
orações eram feitas em uma sala alugada (Ramos 2003: 68). São Bernardo do Campo é conhecida como a cidade dos móveis, ramo em que trabalham muitos muçulmanos que estão no Brasil desde as décadas de 1950 e 1960. Além deste tipo de atividade, o comércio de roupas e tecidos também é considerável entre os árabes muçulmanos dessa região ou das regiões do Brás e de Santo Amaro. Segundo a classificação de Ramos, 58,6\% das lojas da região de São Bernardo do Campo são de libaneses, seguidas pelas de italianos, 13,8\% (2003: 74). Cabe dizer que esse ramo de negócios é característico de comunidades árabes, sejam elas muçulmanas ou não.

Durante o mestrado, tive a sorte de me aproximar de uma muçulmana que mudaria os rumos da pesquisa, por facilitar minha inserção em campo. Magda Aref, estudante, na época, do curso de ciências sociais da FFLCH-USP, ajudou-me na aproximação ao grupo de mulheres do Brás. Com ela, fui aprendendo a me comportar em uma mesquita e, a todo momento, me era revelado o que podia e o que não podia fazer. Magda teve paciência para me apresentar e ensinar muita coisa sobre a religião e o modo de vida de um muçulmano e muito da sua história está em minha dissertação. Tal história encerra tanto seu processo de "reversão" à religião como também outros dados que ajudam a compreender a transformação pela qual passou a comunidade do Brás/Pari na década de 1990.

Tomei nota de fatos ocorridos com Magda e com sua família libanesa. As fotografias faziam parte de nossas conversas e me conduziam a um outro mundo, a outros contextos. Terminado o mestrado em 2001, voltei à comunidade do Brás, em 22 de fevereiro de 2002, quatro meses depois da minha defesa de mestrado. Era o dia do Sacrifício. ${ }^{8}$ Mas era como se voltasse a minha própria casa, pois, após um período de convivência entre eles, é impossível não criar vínculos afetivos, que são correspondidos com abraços e conversas acolhedoras.

Cheguei na hora da oração, no momento em que as mulheres já estavam em seus lugares, no fundo do salão do Centro Islâmico da Liga da Juventude Islâmica do Brás. Lá estavam Magda, Malac, Fátima, Jamel, Rosana, Aicha, Nazek, Gineme e outras. Eu estava feliz por revê-las depois da defesa. Assim, após a apresentação das crianças e da oração, fui ter com as minhas amigas muçulmanas.

Jamel, de imediato, indagou: "E aí, você vai continuar nos estudando?" Balancei a cabeça, dando sinal que sim. Ela, como costumava fazer, caiu na gargalhada e soltou: "Inshalá" (se Deus quiser). Jamel é tia de Magda. Assim como a mãe de Magda, não usa o véu, mas tem o discurso da religião na ponta da língua.

Aproveitei o fato de uma telenovela, exibida pela TV Globo, entre outubro de 2001 e julho de 2002, em horário nobre, ter tratado dos muçulmanos no

8 Relativo à festa do Sacrifício, o Eid Adhha, durante a qual é realizada a matança dos carneiros, a fim de rememorar o sacrifício proposto por Deus a Abraão. Este deveria sacrificar o seu filho em sinal de devoção, mas no momento do sacrifício Deus diz a Abraão para sacrificar no lugar do filho dois carneiros. Ver o vídeo Sacrifício (Ferreira 2007a). 
Brasil e perguntei a Jamel se ela se considerava uma "espetaculosa" como a Nazira, ${ }^{9}$ ou se ela iria "arder no mármore do Inferno" por não usar o véu, como era repetido constantemente na trama folhetinesca. Com desenvoltura, disse-me que prestaria contas no Dia do Juízo, mas com certeza - Inshalá - ela usaria o véu antes de morrer. Em seguida, caiu na gargalhada. Jamel é, sem dúvida, uma das mulheres mais extrovertidas do Brás: falante, alegre, sorridente. Perguntou-me se eu já sabia que sua filha Nedra passara a usar o véu no primeiro dia do Ramadã. Disse que sim. "Pois é", completou, "ela e Magda estão seguindo direitinho o que manda o Alcorão. Isso é motivo de orgulho para nós. Elas são corajosas e isto é um bom exemplo."

Em 2002, participei de aulas de religião para as mulheres, em São Bernardo do Campo. Durante as aulas, ouvi várias vezes do sheik que as ministrava e das próprias mulheres que a educação e a transmissão da religião aos filhos competiam às mulheres e aos homens. Mesmo tendo "responsabilidades" iguais na educação dos filhos, a mulher permanece muito mais tempo com eles, como é possível destacar na fala de Sheik Jihad (um dos sheiks da comunidade de São Bernardo do Campo):

Na realidade a educação é obrigação do casal e não somente da mãe; porém, a mãe, por passar a maior parte do tempo com os filhos, tem uma responsabilidade maior. Há algumas passagens no Alcorão que tratam sobre isto: o profeta Mohamad (SAAWS) ${ }^{10}$ disse: todos são pastores e todos são responsáveis pelo seu rebanho, o governante é um pastor e é responsável pelo seu rebanho, o marido dentro da família é um pastor e é responsável pelo seu rebanho, a esposa na casa do seu marido é uma pastora e é responsável pelo seu rebanho, etc. [versículo 6 da surata "As proibições"; versículo 33 da surata "Os Partidos"; notas do caderno de campo, 2002]

Em sua dissertação de mestrado, Sonia Hamid (2007: 109) ilustra bem o lugar ocupado pelas mulheres palestinas que residem em Brasília, capital do Brasil:

S - E na casa, quem cuida dos filhos, do marido?

A - Quem cuida da casa é a mulher. Dos filhos também. O homem só trabalha fora para trazer dinheiro para casa. Não sabe nada da casa, de criar os filhos. Mas se acontecer alguma coisa errada, a culpa é da mulher.

9 Nazira, personagem de Eliane Giardini na novela $O$ Clone, era uma muçulmana à procura de um marido. Usava decotes ousados, paquerava rapazes. Ser "espetaculosa", para os muçulmanos da novela, era querer chamar a atenção o tempo todo.

10 SAAWS corresponde a "Que a paz e bênção de Deus esteja com ele". 
Hamid afirma que cabe à mulher o cuidado com a casa e com os filhos e ao homem a obrigação de provê-los. Neste sentido, dá destaque à esfera privada como sendo o lugar feminino e à esfera pública como sendo o espaço masculino. É comum aparecer nos discursos que as mulheres são mais "sensíveis", "emocionais", em contraposição aos homens, que são mais "independentes" e "autoritários". São marcas importantes dos discursos, afirma Hamid.

Abu-Lughod (2002 [1998]: 24) considera que, quando se trata de pensar modernidade e Islã, as discussões sempre giram em torno de como se deve educar as mulheres: como administradoras do espaço doméstico, como esposas ou como cidadãs. Dentro desses contextos, continua a autora, se debatem o papel adequado das mulheres em público e as vantagens de educá-las. Neste debate, três pontos foram importantes para esta nova mulher: a educação, o desaparecimento do véu e a participação política. Ser mãe e esposa passou a ser ocupar-se não só da formação de suas crianças, mas também dos problemas relacionados à nação.

A convivência com as mulheres me afetou profundamente, pois foi somente com a aproximação que se tornou possível perceber com acuidade o que é ser muçulmana em São Paulo. O esforço que fazemos para compreender o outro é enorme. E não seria diferente se fosse o contrário - um pesquisador muçulmano que estivesse investigando a nossa cultura -, como bem relatou em sua tese de doutorado Giselle Guilhon:

Imaginemos, por exemplo, o grau de estranhamento que um pesquisador muçulmano poderia experimentar caso tentasse entrar no Vaticano para estudar a vida de São Francisco de Assis. Seriam vários os véus culturais e religiosos que ele teria que transpor para ter acesso ao seu universo de interesse. Da mesma forma, o buscador ou pesquisador ocidental do Sufismo, no seu contato com os especialistas muçulmanos do assunto, depara-se com semelhantes véus: dificuldade com a cultura e a língua do Oriente Médio; hostilidade ou sentimento de superioridade dos religiosos muçulmanos para com os não-muçulmanos; aceitação, por parte dos muçulmanos, de muçulmanos ocidentais convertidos apenas como muçulmanos de segunda categoria; rejeição generalizada do Sufismo pela maioria dos muçulmanos eruditos e políticos ortodoxos; crença, por parte dos sufis islâmicos, na sua superioridade com relação aos muçulmanos não-sufis; posicionamento do Islã como superior ao Judaísmo e ao Cristianismo, apesar de o Islã considerar tanto Abraão quanto Jesus Cristo profetas autênticos, etc. [2006: 258-259]

É nesse sentido que a expressão utilizada pelo Professor Vagner Gonçalves da Silva ${ }^{11}$ em suas argüições é bastante apropriada para pensarmos que não 
somos nós apenas que estamos observando o outro, mas estamos também sendo observados. Silva afirma que, "ao direcionar uma lanterna a nossos pesquisados, estamos também direcionando a nós mesmos essas luzes". Isto implica dizer que, ao vermos, estamos sendo vistos. ${ }^{12}$

Lembro-me de uma conversa que tive com uma muçulmana, durante o mestrado:

Franci - Que graça tem dançar para mulheres verem? Dançar é sensualidade... As festas que vocês organizam só têm mulheres!

Dona Rosana - Quem disse que não dançamos para homens? Dançamos para o nosso marido. E você não dança para o seu marido?

Franci - Eu? Eu não!

Dona Rosana - Então, se você não dançar, alguém vai dançar...

A resposta dada por Dona Rosana chama a atenção do público em geral por dois motivos: primeiro, porque mesmo na academia há muito desconhecimento dos papéis assumidos pelas mulheres muçulmanas - como bem afirma Cardeira da Silva, "o Ocidente conhece a mulher muçulmana, mas continua a conhecer mal as mulheres muçulmanas" (1999: 59-60, grifos da autora) -; segundo, porque a mídia no Brasil contribui para a construção da imagem estigmatizada da mulher muçulmana. Em geral, os não-muçulmanos associam o uso do véu à submissão feminina, deixando de perceber que em vários contextos de diáspora as muçulmanas encontram modos diferentes de aderir ou não ao uso do véu. ${ }^{13}$

Leila Ahmed (1992), em seu livro Women and Gender in Islam, apresenta um histórico sobre a mulher no Oriente, em sociedades islâmicas e não islâmicas, de antes do surgimento do Islã aos dias de hoje, interessando-se pelos discursos sobre gênero, pelo debate entre islâmicos e secularistas, entre advogados do véu e oponentes. Trata-se, portanto, de um estudo dos discursos da mulher em sociedades árabes muçulmanas, dando destaque à dominação masculina em sociedades urbanas. Afirma que, na teoria aristotélica, a mulher não apenas aparece como subordinada social, mas como inferior biologicamente (1992: 29). Um dos pontos interessantes do seu trabalho é considerar que a dominação masculina foi muito mais "leve" no Egito se comparado com a Grécia e a antiga Mesopotâmia, isto porque, segundo ela, a influência européia

12 Márcio Goldman e Viveiros de Castro sugerem uma antropologia pós-social; isto implica que todos são "sujeito" e todos são "objeto", simultaneamente (2006: 182).

13 Há inúmeras formas de problematizar o uso do véu e/ou os códigos impostos pela religião. Como bem ilustra Abu-Lughod (1999), se há o discurso da sociedade oficial, há também a experiência individual. O discurso poético que viola a ideologia da honra e da modéstia de mulheres beduínas, estudadas pela autora, é um bom exemplo. 
e cristã no Egito e, por fim, o sentimento de igualitarismo, humanismo e justiça contribuíram para uma melhor relação de gênero (1992: 33).$^{14}$

A pergunta que podemos fazer é: se elas têm o corpo coberto, será ele modelado pela religião ou pela política? Ou por todas essas coisas juntas? $\mathrm{O}$ véu das mulheres muçulmanas pode ser um marcador sexual-político, mas não é só. As mulheres usam o véu, caracterizam-se como muçulmanas quando se apresentam de véu, dando mostras de como certo discurso sobre o gênero se inscreve no próprio corpo. Como afirma Butler, "discursos, na verdade, habitam corpos... Eles se acomodam em corpos; os corpos, na verdade, carregam discursos como parte de seu sangue... também é uma forma da mulher exercer poder" (em Prins e Meijer 2002: 163).

Com o passar do tempo, senti que, cada vez mais, alguns muçulmanos, principalmente os que me conheciam, atribuíam importância à pesquisa, mesmo não sabendo qual a real dimensão de escrever um trabalho acadêmico. $\mathrm{O}$ simples fato de eu querer entender a religião deles e o seu modo de vida era algo de muito interesse e admiração por parte de alguns na comunidade.

É certo que os estudos feitos por antropólogos em comunidades islâmicas ainda não refletem, completamente, o que foi relatado por Vagner Silva: "O antropólogo ao aproximar-se dessas 'energias' para pesquisar, inevitavelmente acaba sendo atraído por elas... A iniciação do pesquisador, mesmo não sendo uma condição necessária para a pesquisa, é quase sempre vista como uma conseqüência desta..." (2000: 107).

Em conversa com Sheik Jihad, em dezembro de 2006, ficou claro que a comunidade havia aberto as portas à pesquisa. Mesmo assim, muito antes de conversarem comigo, pediam a anuência do sheik, ou, mesmo depois, passavam a ele o que haviam dito a mim, como uma forma de conferir se o que tinham dito era bom ou não. ${ }^{15}$ Trata-se de um controle considerado supostamente necessário, especialmente pelo fato de os muçulmanos se sentirem prejudicados em relação à mídia, embora, no meu caso, não se tratasse de uma jornalista e sim de uma antropóloga. A verdade é que, mesmo sendo bem recebida e tendo alcançado um certo grau de confiança entre muitos muçulmanos, o controle, mesmo implícito, sempre existe. Mas não o considero negativo à pesquisa, ao contrário, ele me ajuda a refletir sobre a relação estabelecida. E se eu fosse muçulmana? A relação seria outra? Seria facilitada?

14 Ver também Mahmood (2006) e Ask e Tjomsland (1998).

15 No documentário que produzi com o título Vozes do Islã (LISA/USP, 25’) problematizei esta questão. Ver em <www.lisa.usp.br>. 


\section{NÃO-NÃO-EU ${ }^{16}$ EM UM ACAMPAMENTO ISLÂMICO}

Contra aqueles que querem passar depressa longe da noção de experimentalismo, continuo convencido de que a forma assumida pela etnografia permanece uma preocupação fundamental na criação de discussões, teóricas e de pesquisa, que confrontam as questões do estilo pós-moderno de produção do conhecimento com as condições sociais reais da pós-modernidade junto aos nossos objetos [...] Mas pode ter certeza de que o objeto de estudo sempre ultrapassa sua delimitação analítica, especialmente sob as condições da pós-modernidade [Marcus 1994: 15].

No sentido de ilustrar a relevância da abordagem da antropologia da experiência (performance) e da antropologia da religião (Islã), passo agora à descrição do acampamento islâmico.

Passada a experiência com a comunidade do Brás, e dando especial atenção ao universo feminino, desejava, então, já há algum tempo, participar de um acampamento islâmico organizado pelos muçulmanos de São Bernardo do Campo. Mas sempre surgia alguma dificuldade quanto à minha imersão neste que é uma espécie de retiro espiritual. Conviver com os muçulmanos, acordar, almoçar, estar presente em suas atividades era do que sentia falta em minha pesquisa. Como um etnólogo que vai à sociedade indígena, desejava estar mais presente na "aldeia”. Estava certa, ao imaginar que estar lá faria diferença. Pensava que lá não haveria nada que me dispersasse, e eu poderia ficar, ouvir, observar, conversar, presenciar tanto os momentos mais sérios quanto os momentos lúdicos, sem ter que retornar à minha casa no final do dia. Para isso tive de persistir e, durante muito tempo, insisti, junto ao Sheik Jihad, sobre minha participação em um acampamento. Observei a ele que esse "mergulho" seria fundamental para um maior entendimento da religião e dos religiosos. No entanto, por duas vezes seguidas não houve vaga, pois a procura para os acampamentos organizados pelos muçulmanos de São Bernardo do Campo costuma ser grande. A afirmação de Sheik Jihad indica minha insistência nessa convivência: "Se não a trouxéssemos [referindo-se a mim], ela tiraria [do ônibus] eu ou Sheik Ali [Abdouni] para vir no nosso lugar, de tanta vontade que tinha de vir!"

Minha persistência e as perguntas "subversivas" foram as características atribuídas por eles a mim. Durante os anos de pesquisa, era comum ouvir:

16 As expressões "eu" e "não-eu" foram cunhadas pelo psicanalista Donald Winnicott (1975 [1971]), quando este refletia sobre a relação entre a mãe e seu bebê. O bebê, por não ter o seu self constituído, funde o seu ao de sua mãe. Por meio da relação da mãe com o bebê é que ele vai conhecendo o mundo e passa a separar o "eu" e o "não-eu". Richard Schechner (1985) faz uso desta expressão para se referir aos papéis assumidos pelo ator. $\mathrm{O}$ ator, em cena, assume o não-eu, da mesma forma que a pesquisadora, em campo, assume outro papel para ser aceita no grupo, mesmo que temporariamente. 
"Você ainda está fazendo sua pesquisa?" Mas chegou um momento em que eles não perguntaram mais, e apenas diziam: "Lá vem a Franci com as suas perguntas subversivas!” O mesmo verifiquei numa outra comunicação: "Mujahad (Alex) - Muito obrigado Francy, mas olha, você é a única subversiva querida por todos na WAMY ${ }^{17}$ viu, veja por esse lado... Suas perguntas eu respondo pessoalmente, no Orkut é tudo muito exposto. Salam" (novembro de 2005).

Eram 16 h00 do dia 23 de julho de 2004 quando embarquei rumo a Sorocaba, local do acampamento, junto com alguns muçulmanos da mesquita de São Bernardo do Campo. O retorno estava marcado para o dia 25 de julho, ao final da tarde. Na bagagem: caderno de campo, gravador, fitas de som, fitas de vídeo, filmadora, tripé, roupas quase "islâmicas", ${ }^{18}$ lenços, etc.

No ônibus, um misto de ansiedade e euforia tomava conta de mim. Conhecia muito pouco os muçulmanos que iam naquele ônibus. Fazia frio e talvez por isso o silêncio tomasse conta de todos. Para passar o tempo, lia uma dissertação de mestrado sobre os conversos de São Bernardo do Campo. Na verdade, li-a quase inteiramente durante o percurso. Por causa do frio, nem senti desconforto com o véu que tive de usar para poder participar do acampamento. De certa forma, ele me ajudou bastante, pois, para muitos, eu era mais uma irmã ${ }^{19}$ entre eles. Cabe refletir sobre a imposição do uso do véu no acampamento, pois talvez esse seja um bom exemplo de como os muçulmanos atuaram em minha pesquisa. Ao participar do acampamento junto com eles, estava presa às regras que me foram impostas, não pelo fato de ser uma pesquisadora ou uma não-muçulmana, mas por ser mulher - as mulheres deveriam usar o véu enquanto estivessem no acampamento.

A chegada a Sorocaba e ao hotel Sol $I_{n n}{ }^{20}$ deu-se às 18 h30. Em geral, esse percurso leva uma hora e meia, mas, com o trânsito de sexta-feira, a viagem foi um pouco mais prolongada. Já no hotel, aguardava o número do meu quarto e a informação de quem seria a minha parceira de quarto. ${ }^{21}$ Até o horário da oração, fiquei no quarto arrumando o material que tinha levado. Às 20h00, fomos todos à mesquita improvisada em um salão acarpetado. Como estávamos viajando no horário da oração da tarde, os muçulmanos fizeram naquele momento as duas orações, a da tarde e a da noite. A primeira foi mais curta que o habitual, por se tratar de uma oração de viajante, isto é, de alguém que está fora de sua cidade, pois atenta-se ao fato de que o viajante pode estar cansado após a viagem. Assim, a oração é reduzida a duas genuflexões, ao invés de quatro, como é usual.

17 WAMY é a World Assembly of Muslim Youth (Assembléia Mundial da Juventude Islâmica).

18 Saias longas, camisas de manga comprida, casacos.

19 Irmã é a forma como os(as) muçulmanos(as) chamam as mulheres muçulmanas.

20 O "acampamento" na verdade é num hotel, e não em barracas como o nome pode sugerir.

21 Logo fiquei sabendo que a minha parceira não viria e acabei ficando sozinha num quarto. 
Logo após a oração, fomos jantar e assistir à abertura do evento. A comida era servida em balcões. A pedido do sheik foram formadas duas filas, uma de homens, outra de mulheres, que corriam lado a lado, marcando a separação entre os sexos, assim como nos quartos, onde havia uma ala feminina e outra masculina. ${ }^{22}$

Durante o jantar pude fazer meus primeiros contatos. Sentada ao lado de Nádia Hussein, esposa do Sheik Jihad, fui conhecendo suas irmãs de Florianópolis e do Rio de Janeiro. Apresentada como amiga dela e do sheik, logo me aproximei de Fadwia e Jamile. Ambas eram bem jovens; Fadwia, de 19 anos, é estudante de administração de empresas em Florianópolis e Jamile é casada, tem 21 anos e cursa direito no Rio de Janeiro. Através delas conheci Kátia, de 30 anos, casada, também residente no Rio. Naquele momento comecei a me soltar, cada uma contava coisas da própria vida para as outras. Falamos sobre tudo: religião, casa, família, faculdade, etc.

Após o jantar, assistimos à abertura do evento. Foi uma apresentação comum aos propósitos de qualquer cerimônia religiosa. Foram feitas recomendações aos jovens para que não ficassem acordados durante a noite, pois deveriam seguir um horário islâmico, e não britânico. Quando ouvi "horário islâmico", logo entendi que isso se referia ao fato de eles fazerem cinco orações diárias, em horários marcados de acordo com a lua. Assim, no dia seguinte, deveríamos acordar às $4 \mathrm{~h} 30$ para rezar, ou seja, eles para rezarem, eu para observar. Fomos dormir às $23 \mathrm{~h} 30$. As regras estabelecidas naquela noite indicavam claramente qual era o propósito daquele encontro: transmitir os valores da religião. E para isso era necessária a divisão em alas, feminina e masculina. Até mesmo quando ouviam as palestras ou almoçavam, deveriam se sentar em alas separadas.

Às 4 h30 já estava de pé. Tomei um banho para acordar e peguei o equipamento. Fui uma das primeiras a chegar, pois queria gravar a oração e tudo o mais que acontecesse. Das 5 h00 às 6h 15, mais ou menos, eles rezaram. As mulheres que, por estarem menstruadas, ${ }^{23}$ não podiam rezar, assistiam sentadas à oração. Âs $6 \mathrm{~h} 30$ formaram-se grupos para recitar o Alcorão. Aquelas que conheciam as suras ajudavam outras muçulmanas a decorar. Foi um momento especial. As mulheres pronunciavam o Alcorão com calma, algumas tentavam acompanhar a pronúncia, o ritmo, e assim foi até às $7 \mathrm{~h} 30$, hora do café (e realmente eu precisava de um para poder acompanhar aquele horário islâmico).

Durante o café, muitas queriam saber se eu estava gostando, se eu tinha passado bem à noite e sobre a minha experiência no acampamento. Fui apresentada a Jalila, uma jovem psicóloga - que acabaria por apresentar seu

22 Nesse primeiro dia resolvi não gravar nada, deixei o material guardado, nem mesmo carreguei comigo o caderno de campo. Achei melhor me inteirar da programação, já que, até o momento, não sabia de fato o que aconteceria.

23 A menstruação é considerada impureza legal (Bouhdiba 2006: 75). Por essa razão, a mulher fica dispensada de rezar e de fazer jejum, restituindo essas obrigações em uma data posterior. 
trabalho de conclusão de curso (TCC) sobre o uso do véu - e a conversa se estendeu bastante, apesar do sono que se abatia sobre nós duas. Ela, filha de uma brasileira e um palestino, aprendeu a religião com o pai, mas não usa o véu, talvez, segundo ela, porque esse não seja o hábito de sua mãe.

Às 9h00 teve início a palestra sobre os Pilares do Islã, ministrada pelo Sheik Jihad. A palestra era praticamente a mesma que tinha sido dada por ele a estudantes de uma universidade. Mais longa, porém, porque ele a entrecortava com outros exemplos, e um pouco diferente, pois ele parecia muito mais duro com os muçulmanos do que com os não-muçulmanos. ${ }^{24}$

Na hora do almoço, "perdi" 25 a oportunidade de gravar belos depoimentos. Nos sentámos, Jalila, Fawdia, Jamile e eu, e nos pusemos a falar sobre discriminação e preconceito e sobre a tensão entre brasileiros e árabes. A própria Jalila dizia ter sido discriminada, anos atrás, por ser filha de brasileira, ${ }^{26}$ mas que, durante sua pesquisa para o TCC, esse sentimento se esvaiu. Jamile opinou que quem discrimina não conhece o verdadeiro Islã. ${ }^{27} \mathrm{O}$ Islã não prega isso. "O Profeta Muhammad (SAAW) pregava o respeito por outros povos". Em meio à conversa, vinha-me à memória, o tempo todo, um texto de Todorov (1988) sobre igualdade e desigualdade, e soltei uma frase: "A diferença é ser diferente, e não desigual." As três juntas exclamaram: "Que bonito! Repete." "Eu não sei mais" - respondi. E foi aí que Fadwia repetiu a frase...

Não falávamos somente sobre desigualdade, em nossa mesa, mas também sobre os migrantes muçulmanos que, quando chegavam ao Brasil, pediam para que suas mulheres tirassem o véu, pois assim chamariam menos a atenção. O que era comum em países como o Líbano, não o era no Brasil daquele período. Da década de 1990 para cá, esse sentimento vem mudando. As mulheres têm sido estimuladas a usar o hijab. Jamile contou que foi em um acampamento que ela passou a usar o véu: "Coloquei ali e nunca mais tirei." Cabe registrar que nos acampamentos todas as mulheres são obrigadas a usar o véu, e a justificativa para isso é o aprendizado, a experiência, ou seja, se não passarem pela experiência de usá-lo durante um final de semana, nunca saberão se serão ou não capazes de usá-lo no cotidiano.

24 Em palestras de Sheik Jihad realizadas em universidades e gravadas por mim, ele me pareceu muito mais contemporizador do que nesta palestra aos muçulmanos. Isso me fez perceber que as performances são geradas de forma diferente, dependendo de quem é o grupo com o qual se dialoga. Um muçulmano deve aprender e praticar o modo correto, mas o não-muçulmano deve apenas conhecer.

25 Nada melhor do que a sensibilidade de quem está atento às falas, aos olhares, aos mínimos gestos que ocorrem nestes momentos em que o caderno de campo ficou esquecido num canto. Como afirma Grimes (1995: 17), "caneta e papel são objetos poderosos, fetiches".

26 Da mesma forma que com sua mãe, o preconceito em relação a ela, que era brasileira, era sentido da parte de mulheres árabes.

27 Quando ela se refere a um Islã verdadeiro, está implícito que não é este que é combatido cotidianamente pela imprensa ou por pessoas que não conhecem a religião. É a um Islã que prega a paz e a justiça social que ela se refere, e não a um Islã que é sempre mal interpretado. 
Já eram 15 h00 e ainda não tínhamos nos arrumado para ir à fazenda. Esse foi um momento de lazer durante o acampamento. Muitas mulheres vieram preparadas, de tênis e agasalho, para jogar vôlei. Algumas me perguntaram se eu jogaria vôlei com elas; disse que, por enquanto, eu não estava dando conta de usar o véu "paradinha", quanto mais pulando e saltando. A risada foi geral. Na verdade, comer macarronada de véu já tinha sido um grande desafio, imagine jogar vôlei. Durante esses anos de pesquisa, havia usado o véu apenas para entrar na mesquita, por isso senti nesse momento tanto desconforto. Quando estava no meu quarto, a primeira coisa que eu fazia era tirar o véu. Era a falta de hábito. Nesse sentido, devo considerar que usar o véu não é simplesmente colocá-lo; aprender a usá-lo é uma experiência constitutiva da vida dessas mulheres.

No passeio ao Parque Florestal Ipanema, que divide as cidades de Iperó e Araçoiaba da Serra, fomos todas em um mesmo ônibus. Ao chegar no parque, o ônibus, cheio de mulheres usando véu, transformou-se no grande atrativo das pessoas que passavam pelo lugar. A cena delas olhando para as mulheres dentro do ônibus e depois fora dele era bastante intrigante: olhares curiosos de quem parecia estar vendo as irmãs de Bin Laden, como elas mesmas brincavam. Elas se divertiam, querendo descer logo do ônibus.

$\mathrm{Na}$ volta ao hotel, a brincadeira era geral dentro do ônibus. Cantavam uma música comum para as crianças: "O Fulano roubou pão da casa de João. Quem? Eu? Eu não! - Então, quem foi? Foi a Nadia. A Nadia roubou pão na casa do João..." Chegamos ao hotel às 18 h45. Só desejava tomar um bom banho e comer. Enquanto me preparava para o banho, elas se preparavam para a reza. Eis uma das diferenças entre elas e eu: eu estava preocupada em trocar de roupa, tirar o véu e depois jantar, mas elas ainda tinham, no meio do caminho, uma oração para fazer em comunidade. A convivência e a proximidade revelam as diferenças. Esse foi o meu tempo de descanso, das $18 \mathrm{~h} 45$ às $20 \mathrm{~h} 00$, horário da gincana. $\mathrm{O}$ jantar foi às $21 \mathrm{~h} 00$.

A gincana era de homens versus mulheres. Participei da brincadeira, que tinha desde "Imagem-Ação" (um jogo em que você tem que adivinhar quem é a pessoa) até perguntas sobre o Islã. As mulheres levaram a melhor e ganharam de longe aos homens. Elas fizeram grito de torcida. Realmente estavam competindo e levando a sério a brincadeira.

Após o jantar, uma garota pediu ao Sheik Jihad uma palestra para os participantes do acampamento, para tirar dúvidas, etc. Tinha uns catorze anos e logo percebi o motivo de pedir ao sheik mais uma palestra depois do jantar. Certa de que estávamos todas cansadas, não poderia ser pela religião, mas por algum interesse, que ela me revelou ao pedir-me que convencesse o sheik a falar mais sobre religião. Na verdade, queria olhar mais um pouco para um determinado rapaz. Não precisei pedir nada, nem faria isso. A palestra do sheik aconteceu, mas só para mulheres, com grande desapontamento da garota que 
pretendia estar mais próxima de um determinado jovem que participava do acampamento.

Lá fomos nós às $22 \mathrm{~h} 00$ ouvir o sheik. Uma das participantes perguntou por quê não havia sheiks mulheres e quis saber por quê ela não havia sido avisada com antecedência sobre o acampamento. Disseram-lhe que as informações não chegaram a tempo à sua cidade, no sul de Santa Catarina. As indagações dessa mulher mostram que os fiéis também questionam a maneira como a religião é estruturada nas atitudes cotidianas. Outras mulheres disseram que quem tinha interesse devia correr atrás. Olhava para o relógio: 23h25. Meus olhos queriam se fechar. O sheik da Arábia Saudita veio pedir ao Sheik Jihad para encerrar a conversa. A essa altura, os homens já estavam em seus quartos. Enfim, fomos dormir. Decidi que não acordaria para a oração das 4h30, já havia gravado no sábado, não haveria necessidade de repetir a oração novamente.

Durmo. O telefone toca. São $2 \mathrm{~h} 30$ da madrugada. Um homem pergunta: "Quem fala?" Respondo: "Franci." "Hora da reza", diz a voz do outro lado. “Já?!", imaginei responder.

Olho para o relógio... Pensei: não levanto mesmo. Só fui levantar às 6h00, depois de ouvir várias batidas nas portas dos quartos para que as meninas se levantassem. Fui direto à mesquita e descobri que o telefonema recebido na madrugada havia sido trote e que várias meninas haviam se levantado e feito a ablução, ${ }^{28}$ etc. Na porta da mesquita (na sala de oração) encontro Sheik Jihad, que me cumprimenta:

Sheik Jihad - Assalamu aleikum!

Franci - Aleikum me salam!

Sheik Jihad - Este acampamento está sendo bom para sua pesquisa apenas ou também para você como pessoa?

Franci - Não há como separar a pessoa da pesquisadora, afirmei. Aprendemos juntas, completei a seguir.

Seu sorriso foi sinal de que a resposta, por enquanto, bastava. Realmente não tinha parado para pensar nisso, se a experiência do acampamento só era algo a acrescentar à minha pesquisa ou também ao meu cotidiano. Na verdade, não costumo separar, como disse a ele, a pesquisadora da pessoa. A constituição

28 A seqüência que os muçulmanos costumam seguir nas abluções - wudhu - começa pela lavagem das mãos e dos pulsos (antes pronunciam: "Bismillahir rahmanir-rahim" - Em nome de Deus, o Clemente, o Misericordioso); depois enxáguam a boca três vezes e lavam o nariz e o rosto. Em seguida, devem lavar os braços até o cotovelo, passar as mãos molhadas na cabeça e nas orelhas e, para finalizar, lavar os pés até os tornozelos três vezes, começando pelo pé direito, lavando-se, inclusive, entre os dedos. Finalizada a ablução deve-se dizer: "Ach hadu na la ilaha illallah wa ach-hadu anna Muhammadan raçulullah" (Testemunho que não há outra divindade além de Deus e que Muhammad é o mensageiro de Deus). 
de uma pesquisa é também a constituição da pessoa. E as duas com certeza são bastante problemáticas.

Tal episódio me fez lembrar de um outro, ocorrido quando levei Magda Aref para falar a alunos de psicologia de uma universidade. Uma aluna fez uma determinada pergunta e Magda, na hora de responder, disse: "Vou responder como muçulmana." A aluna retrucou, afirmando: "Não quero que você responda como muçulmana, mas como pessoa." Naquele momento, fiquei bastante irritada com a postura da aluna. Como separar a pessoa da sua religião? Como separar a pesquisadora da experiência? Uma não existe sem a outra, hoje sei.

$\mathrm{Na}$ hora do almoço já me sentia à vontade entre as mulheres. A conversa agora era com as mulheres que vieram do Pari. Conversávamos sobre vídeos iranianos e, em um determinado momento, afirmei: "Eu adoro filme iraniano!" Uma delas, Latifa, olhou para mim e disse: "Adora não, irmã. Gosta muito. Nós só adoramos a Deus." Percebi que ela ainda considerava que eu era muçulmana, e respondi: "Eu adoro, porque eu não sou muçulmana. Você, sim, deve adorar só a Deus."

Ela se justificou dizendo que eu deveria me preparar para me tornar muçulmana e, para isso, era bom aprender como se fala. Nos termos "nativos", a idéia de Deus é interessante para pensar, assim como os pecaris interessam aos índios, como nos mostra Viveiros de Castro: "a idéia de que os pecaris são humanos me interessa, a mim também, porque 'diz' algo sobre o que é ser 'humano"' (2002: 134).

É importante frisar que, ao falarem de Deus, os muçulmanos estão falando deles mesmos e de Deus. Daí a grande intuição de Viveiros de Castro (2002): não cabe ao antropólogo acreditar ou não no que os nativos acreditam, mas compreender o que isso ensina sobre os nativos.

No início deste texto levantei a idéia de que ser mulher em campo faz diferença. No acampamento isto ficou bem demarcado, pois, embora não fosse muçulmana, fui tratada como se fosse uma delas. Sendo mulher, minha participação no acampamento era totalmente voltada ao universo feminino. Como poderia eu sentar à mesa com os homens para almoçar? Usando véu, ficava "explícito" qual era o meu tipo de participação no acampamento. Antropólogos não andam com crachás que os identifiquem como antropólogos. A maneira que encontrei para me aproximar dos homens foi por intermédio dos sheiks, que me conheciam e sabiam o que eu estava fazendo ali.

Em eventos anteriores, Sheik Jihad disse-me que, pelo fato de conhecer tanto o Islã, um dia me tornaria uma irmã, pois os meus conhecimentos me levariam a isso. Para um pesquisador, suas escolhas nunca são tão claras e evidentes, às vezes são casuais e/ou por gosto, estilo, etc. O que construí em campo foi um diálogo constante, a ponto de eles "palpitarem" ou, de certa forma, dialogarem a respeito dos significados que eles mesmos atribuem ao que fazem ou deixam 
de fazer, mas sem perder de vista a minha própria opinião. O que busco fazer é tentar "traduzir" o que experimento e o que compartilho com eles: se não a religião, a percepção desta experiência de ser muçulmano. De lugares diferentes, vamos nos mexendo, pouco a pouco, e calculando o lugar de onde olhamos ou nos olhamos.

No final do acampamento, recebi uma homenagem. O sheik se referiu a mim como uma amiga da comunidade muçulmana e convidou-me para passar um Carnaval entre eles, ou melhor, num acampamento islâmico. Dessa vez, não mais convidaram a Franci ou a antropóloga, mas ambas. Segundo Vagner Silva: "O grupo também mobiliza seu sistema de classificação para tornar aquele que inicialmente era um 'estrangeiro' em uma 'pessoa de dentro', isto é, um sujeito socialmente reconhecido" (2000: 88).

É possível concluir por ora que, se, por um lado, ser mulher, mãe e antropóloga contribuiu para uma aproximação entre mim e os muçulmanos, também tornou claras as diferenças entre a pesquisadora e o grupo pesquisado. Como venho argumentando, a pesquisadora, assim como observa, também é observada. O que de fato aprendemos é a lidar com o campo etnográfico e suas nuanças. Um pesquisador do Islã confessou-me o quanto foi difícil para ele entrevistar as mulheres, que só aceitaram responder a suas perguntas porque quem as fazia era sua esposa, limitando assim uma maior aproximação dele às mulheres. Isso eu realmente nunca observei em relação à minha pesquisa homens se negarem a conceder uma entrevista, por eu ser mulher -, mas também não quer dizer que eles fizessem as suas concessões sem consultar o sheik a meu respeito, para saber quem eu era, etc.

\section{NA BATIDA DO PULSO: REVELANDO PROBLEMAS}

Of all the human sciences and studies anthropology is most deeply rooted in the social and subjective experience of the inquirer. Everything is brought to the test of self, everything observed is learned ultimately "on his (or her) pulses" [Turner 1986: 33]. ${ }^{29}$

Quando se determina um problema de pesquisa como o que constrú, temos de pensar de que forma vamos atingi-lo e compreendê-lo. Para isso, traçamos um percurso que seguimos e nos propomos objetivos que nos coloquem em uma trilha a ser percorrida. Entender o universo do muçulmano, seja "reverso" ou não, brasileiro ou não, requer uma estratégia que não se restringe a formular perguntas e a coletar respostas, pois, às vezes, essas respostas só são encontradas

29 "De todos os estudos e ciências humanas, a antropologia é a que está mais profundamente enraizada na experiência social e subjetiva do investigador. Nela, toda avaliação tem como referência o sujeito, toda observação é finalmente apreendida "na batida do pulso'" (tradução de Herbert Rodrigues). 
na observação, na própria esfera do sensível, do compartilhar alguns elementos ou momentos que sejam relevantes para aquele grupo. Temos também de falar do assunto que interessa a esse grupo. Como bem observa Goldman:

O cerne da questão é a disposição para viver uma experiência pessoal junto a um grupo humano com o fim de transformar essa experiência pessoal em tema de pesquisa que assume a forma de um texto etnográfico. Nesse sentido, a característica fundamental da antropologia seria o estudo das experiências humanas a partir de uma experiência pessoal [2006: 167].

Estar entre eles é também estabelecer laços afetivos. É uma amizade que vai sendo construída, a ponto de eles não fecharem o seu universo, com medo de que sua realidade seja deturpada. Para muitos, é certo que vou apresentar os conflitos. Sabem que há um hiato a ser preenchido. Busco mostrá-lo de forma que entendamos alguns modos de ser muçulmano no Brasil, em São Bernardo do Campo, ou seja, dando um passo para entender o ethos islâmico.

O acampamento contribuiu para experienciar o ser muçulmano. O véu serviu de máscara, não no sentido de esconder algo, mas de revelar algo. Mostrar-me perto deles para entendê-los, era essa a questão inicial. A produção de imagens ampliou o meu olhar; outros modos de ver e ouvir também nos conduzem à reflexão. O diálogo é ampliado, tanto dentro quanto fora da comunidade. É um estar lá e editar aqui, tarefa complexa, mas fundamental para implementar o conhecimento.

Além de verificar o meu lugar como estrangeira, a diferença ali também revela a outra face daquela que observa a religião, ou que pelo menos a tangencia, como é o meu caso, pelo fato de estudá-los e ser para eles, ao mesmo tempo, uma futura "reversa". Se já conheço a religião e já entendo bastante da sua história, etc., então nada mais previsível do que a minha "reversão".

É difícil para aquele que tem uma crença entender que uma pessoa possa ser apenas pesquisadora e gostar muito do que faz. Estar neste lugar não é simplesmente cômodo, pois podemos ocasionar, no outro, determinadas expectativas que, em muitos casos, não serão correspondidas. Ler, aprender, observar, compartilhar esse universo são caminhos fundamentais para quem pretende avançar no conhecimento de determinado tema. Mas, para quem está do outro lado, para aquele que vivencia a religião, que lê com outra finalidade, que reza, que acredita, talvez seja realmente muito difícil entender como nós antropólogos podemos fazer tudo isso e continuarmos à parte, ou seja, não compartilharmos dos mesmos "segredos" e das mesmas "cosmologias".

Assim, entendo a questão do sheik: "Afinal, para que serve esse acampamento?" Se esta pergunta encerra várias interrogações, também esclarece o meu posicionamento, porque eu não sou muçulmana e o meu lugar, portanto, é outro, é um lugar construído, performatizado, tanto quanto o dos próprios 
muçulmanos. A relação construída entre pesquisadora e grupo pesquisado só tem sentido porque há uma elaboração, uma aceitação, um espaço negociado por ambas as partes num diálogo constante, porque, de certa maneira, todos nós somos afetados. É nesse sentido que penso em performance da pesquisadora. A noção de performance, para Richard Schechner (1985), não é meramente a performance em si, mas um grande ensaio, uma repetição. O que faz o pesquisador, senão ensaiar perguntas, atitudes, pergunta ele? $?^{30}$

Termino este tópico constatando aquilo que já foi experienciado por Victor Turner (1982) e retomado por Schechner, quando este afirmou: "Fazer os movimentos do Nô, mesmo que por um breve período, me ensinou mais no meu corpo que páginas de leitura" (1985: 31). É a experiência com a etnografia performativa que também encontrei nesse acampamento islâmico, pois me comportava "como se" fosse um deles. Este estado de subjuntividade ${ }^{31} \mathrm{com}$ certeza ampliou os meus sentidos em relação ao grupo que estava pesquisando. A partir dessa experiência, surgia a pesquisadora-performer e os limites e as potencialidades da etnografia performativa.

\section{BIBLIOGRAFIA}

ABRANCHES, Maria, 2007, "Muslim women in Portugal: strategies of identity (re)construction”, Lusotopie, 14 (1): 239-254.

ABREU, Carolina, et al., 2003, "Entrevista com Mariza Côrrea", Cadernos de Campo: Revista dos Alunos de Pós-Graduação em Antropologia Social da USP, 11: 103-122.

ABU-LUGHOD, Lila, 1999, Veiled Sentiments. Berkeley, Los Angeles e Londres, University of California Press.

—-, (ed.), 2002 [1998], Feminismo y Modernidade en Oriente Próximo. Valência, Ediciones Cátedra, Universitat de Valência, Instituto de la Mujer.

AHMED, Leila, 1992, Women and Gender in Islam: Historical Roots of a Modern Debate. New Haven, CT, Yale University Press.

AL-ALI, N., R. BLACK, e K. KOSER, 2001, “The limits to 'transnationalism': Bosnian and Eritrean refugees in Europe as emerging transnational communities", Ethnic and Racial Studies, 24 (4): 578-600.

30 Vale a pena lembrar que a antropologia da performance é parte da antropologia da experiência.

31 Turner cita o Webster's Dictionary: o subjuntivo sempre tem a ver com "desejo, possibilidade, ou hipótese"; é o mundo do "como se", que abrange desde a hipótese científica à fantasia da festa. É o "como se fosse", em vez do "é". Trata-se de expressar algo possível ou simplesmente desejado (Turner 1982: 82-84). 
ALMEIDA, Heloisa, Buarque de, 2001, "Mulher em campo: reflexões sobre a experiência etnográfica”, em H.B. de Almeida et al. (orgs.), Gênero em Matizes. Bragança Paulista, EDUSF, 49-80.

ANDEZIAN, Sossie, 1986, “Women's roles in organizing symbolic life: Algerian female immigrants in France”, em Rita James Simon e Caroline B. Brettell (orgs.), International Migration: The Female Experience. Totowa, NJ, Rowman and Allanheld, 254265.

ASK, K., e M. TJOMSLAND, 1998, Women and Islamisation: Contemporary Dimensions of Discourse on Gender Relations. Oxford, Berg Publishers.

BOUHDIBA, Abdelwahab, 2006, A Sexualidade no Islã, São Paulo, Globo.

BRUNER, Edward M., 1986, "Experience and its expressions", em Victor Turner e Edward Bruner (orgs.), The Anthropology of Experience. Chicago, University of Illinois Press, 3-30.

BUTLER, Judith, 2003a, Problemas de Gênero. Rio de Janeiro, Civilização Brasileira.

— 2003 b, "Corpos que pesam: sobre os limites discursivos do 'sexo'”, em Guacira Lopes Louro (org.), O Corpo Educado: Pedagogias da Sexualidade. Belo Horizonte, Autêntica, 151-172.

CALDEIRA, Teresa P.R., 1988, "A presença do autor e a pós-modernidade em Antropologia", Novos Estudos CEBRAP, 21: 133-157.

CLIFFORD, James, 1998, A Experiencia Etnográfica: Antropologia e Literatura no Século XX. Rio de Janeiro, Editora da UFRJ.

DRUMMOND DE ANDRADE, 1999, "Poema de sete faces", em Carlos Drummond de Andrade, Sentimento do Mundo. Rio de Janeiro, Record, 11.

FAVRET-SAADA, Jeanne, 2005, "Ser afetado", Cadernos de Campo: Revista dos Alunos de Pós-Graduação em Antropologia Social da USP, 13: 155-161.

FERREIRA, Francirosy C. B., 2001 , Imagem Oculta: Reflexões sobre a Relação dos Muçulmanos com as Imagens Fotográficas. São Paulo, FFLCH-USP, dissertação de mestrado.

— - 2002, "A linguagem fotográfica no Islã", Travessia: Revista do Migrante, 42: 22-28.

_, 2004 , "Cavalo de bronze: caligrafia e palavra", em Andréa Barbosa et al. (orgs.), Escrituras da Imagem. São Paulo, EDUSP, $121-131$.

— 2006, "A imagem do Profeta: proibir por quê?", Cadernos de Antropologia e Imagem, 22: 95-111.

— , 2007, Entre Arabescos, Luas e Tâmaras: Performances Islâmicas em São Paulo. São Paulo, FFLCH-USP, tese de doutorado.

—_, 2009, "Abelhas, aranhas e pássaros: imagens islâmicas em movimento", em A. Barbosa, E. Cunha e R. Hikiji (org.), Imagem-Conhecimento: Antropologia, Cinema e Outros Diálogos. São Paulo, Papirus.

GODINHO, Susana, C. M., 2007, Novos Possíveis: Estratégias Identitárias de Mulheres Oriundas da Guiné-Bissau em Portugal. Lisboa, ISCTE, dissertação de mestrado.

GOLDMAN, Marcio, 2006, "Alteridade e experiência: antropologia e teoria etnográfica", Etnográfica, X (1): 161-173.

GOLDMAN, Marcio, e Eduardo VIVEIROS DE CASTRO, 2006, "Abaeté: rede de antropologia simétrica". Cadernos de Campo: Revista dos Alunos de Pós-Graduação em Antropologia Social da USP, 14-15: 177-190.

GRIMES, Ronald, 1995, Beginnings in Ritual Studies. Columbia, SC, University of South Carolina Press, $3 .^{\mathrm{a}}$ ed. revista. 
GuilHon, Giselle Antunes Camargo, 2006, A Arte Secreta dos Dervixes Giradores: Um Estudo Etnocenológico do Sama Mevlevi. Salvador, Universidade Federal da Bahia, tese de doutorado. HAMID, Sonia, 2007, Entre a Guerra e o Gênero: Memória e Identidade de Mulheres Palestinas no Brasil. Brasília, DF, Universidade de Brasília, tese de mestrado.

HIKIJI, Rose S. G., 2006, A Música e o Risco. São Paulo, EDUSP.

MAHMOOD, Saba, 2006, “Teoria feminista, agência e sujeito liberatório: algumas reflexões sobre o revivalismo islâmico no Egipto”, Etnográfica, X (1): 121-158.

MARCUS, George E., 1994, “O que vem (logo) depois do 'pós': o caso da etnografia”, Revista de Antropologia, 37: 7-34.

MERNISSI, Fatima, 1999 [1994], Sonhos de Transgressão: Minha Vida de Menina num Harém. São Paulo, Companhia das Letras.

PRINS, Baukje, e Irene Costera MEIJER, 2002, "Como os corpos se tornam matéria: entrevista com Judith Butler", Revista de Estudos Feministas, 10 (1), 155-167.

RAMOS, Vlademir Lúcio, 2003, Conversão ao Islã: Uma Análise Sociológica da Assimilação do Ethos Religioso na Sociedade Muçulmana Sunita em São Bernardo do Campo na Região do Grande ABC. São Paulo, Universidade Metodista, dissertação de mestrado.

SALIH, Ruba, 2003, Gender in Transnationalism: Home, Longing and Belonging among Moraccan Migrant Women. Londres e Nova Iorque, Routledge.

SILVA, Maria Cardeira da, 1999, Um Islão Prático: Quotidiano Feminino em Meio Popular Muçulmano. Oeiras, Celta Editora.

—, 2004 , "De que gênero é o Norte de África? Reflexões em torno da produção de antropologia, género e território em contexto africano", comunicação no congresso Africa Camina: Estudos Ibéricos sobre África, Barcelona: ARDA/Generalitat de Catalunya/LISA, 12-15 de Janeiro (disponível em <http://www.box.net/shared/2e48f3580t>).

SILVA, Vagner G., 2000, O Antropólogo e Sua Magia. São Paulo, EDUSP.

SCHECHNER, Richard, 1985, Between Theater and Anthropology. Filadélfia, University of Pennsylvania Press.

TODOROV, Tzvetan, 1988, A Conquista da América: A Questão do Outro. São Paulo, Martins Fontes.

TURNER, Victor, 1982, From Ritual to Theatre. Nova Iorque, Performing Arts Journal Press.

— 1986, "Dewey, Dilthey, and drama: an essay in the anthropology of experience", em Victor Turner e Edward M. Bruner (orgs.), The Anthropology of Experience. Urbana e Chicago, University of Illinois Press (tradução portuguesa de Herbert Rodrigues em Cadernos de Campo, 13, 2005).

VIVEIROS DE CASTRO, Eduardo, 2002, “O nativo relativo", Mana, 8 (1): 113-148.

WINNICOTT, D. W., 1975 [1971], O Brincar \& a Realidade. Rio de Janeiro, Imago Editora. WANIEZ, P, e V. BRUSTLEIN, 2001, Os Muçulmanos no Brasil: Elementos para uma Geografia Social. Rio de Janeiro, Alceu.

\section{FILMOGRAFIA}

FERreIRA, Francirosy C.B., 2006, Allahu Akbar. São Paulo, Laboratório de Imagem e Som em Antropologia/USP.

—_, 2007a, Sacrifício. São Paulo, Laboratório de Imagem e Som em Antropologia/USP.

— 
More than a thousand nights of ethnographic experience: a methodological construction for researcher-performers of religion - Francirosy Campos Barbosa Ferreira - Instituto de Artes/Unicamp; Gravi/USP; Napedra, Brazil • francirosy@gmail.com

This essay presents an ethnographic experience which took place in two Muslim communities, in São Paulo and São Bernardo do Campo, Brazil, as part of my doctoral field work. This research not only establishes an interesting dialogue between the anthropology of performance of Richard Schechner and Ronald Grimes and the anthropology of experience of Victor Turner, but also evokes Favret-Saada's theory of affectivity. In this way, an attempt is made to develop a methodology capable of dealing with questions of both the anthropology of performance and the anthropology of religion. The objective are threefold: a) to discuss the place of the researcher as a performer (as a woman, mother and anthropologist), within the framework of a performing ethnography; b) to present the course which this ethnography made possible; and c) to highlight the experience which took place in an Islamic camp.

KEYWORDS: anthropology of performance, anthropology of religion, Islam, gender, ethnography, methodology. 